\section{Births to single mothers and non-married couples}

Sir - A correlation between high birth rate and low suicide rate is cited as supporting a Social Integration Factor as a protector against suicide.' On the other hand, the contribution of births to single mothers and births to non-married couples forms a large proportion of the current Irish birth rate, and has done so for some years. In the past this would be seen as an indicator of a decrease in the Social Regulation Factor, tending to increase the suicide rate rather than the reverse. It may well be the case, however, that a significant shift in social attitudes has now occurred and that births outside marriage are now accepted as the social norm in Irish society, as has happened in many of our European neighbours over the past 30 years.

Peter Kirwan, $M B, M R C P s y c h, F R C P C$, Clinical Director, Mid Western Health Board, Regional General Hospital, Limerick, Ireland

1. Connolly J, Lester D. Suicide rates in Irish counties. Irish Journal of Psychological Medicine 2000; 17(2): 59-61.

\section{Outpatient clinics}

Sir - In their topical article on outpatient clinics in Ireland's Eastern Health Board Region,' Dr Winifred $O$ Neill and her colleagues state that the first community psychiatric outpatient clinic (OPD) was established in the Eastern Health Board (EHB) region in the mid 1960s. In actual fact development in community psychiatry took place well before that. With the passage of the Mental Treatment Act 1945, which came into force on January 1, 1947 for the first time psychiatrists were allowed to conduct outpatients clinics. Section 222A37 of the Act stated: "A Mental Hospital Authority may, subject to the sanction of the Minister, arrange for the provision of preventive or aftercare services for any chargeable patient ordinarily resident in their mental district."

Long before McKinsey ever thought of the creation of the Eastern Health Board, the Grangegorman Mental Hospital Board's chief psychiatrist, Dr John Dunne commenced his weekly outpatient clinic in Mercer's Hospital. Being lreland's first Professor of Psychiatry at UCD, he attracted many students to his clinics in the 1950 s where we learned the basics of history taking and the methods of outpatient treatment. The theory and practice then was not much different from many of today's operations. Dr John Cullen on his return from Cambridge University to St Brendan's Hospital had his outpatient clinic in the annex before 1961 .

Dr Evelyn O'Brien, working out of St Brendan's Hospital started an OPD in Ballyfermot in about 1960.

By September 1963, 7,600 patients attended outpatient clinics in the then Dublin Health Authority Area. In the first nine months of 1964 up to 13,000 people attended these outpatient clinics. This Authority was established in July 1960 and continued to 1971 when the Eastern Health Board was formed.

Shortly after his appointment as Medical Director of St Patrick's Hospital, Dr Norman Moore had an outpatients clinic for private patients and Dr Frank McLoughlain had an OPD in St Vincent's Hospital on St Stephen's Green in the early 60 s.

It is interesting to read through the Manager's Monthly Reports of the Dublin Health Authority and find no reference being made to the development of outpatient clinics till late in the $1960 \mathrm{~s}$. These initiatives by a few dedicated doctors were given no formal recognition by the authorities at the time and were operated almost 'by stealth'.

In fact, the pool system of payment for consultants in the Voluntary Hospitals operated at this time and continued till after the implementation of the Common Contract for Consultants. Because of that consultants had to have permission from the Department of Health to start an OPD but I can recall this order being ignored by those of us working in the public service. We had "an Irish Solution to an Irish problem".

Brian McCaffrey, Psychiatrist, Portmarnock, Co Dublin, Ireland.

\title{
Letters to the Editor
}

should be addressed to:

The Editor

Irish Journal of Psychological Medicine

25 Adelaide Street, Dun Laoghaire, Co Dublin, Ireland. Fax: 01-280 7076

Email: psychological@medmedia.ie 